\title{
ホームサーバのシステム設計 System Design for Television Home Servers
}

\section{栗岡 辰弥 沼澤 潤二 \\ NHK放送技術研究所}

\section{Tatsuya Kurioka Junji Numazawa NHK Science \& Technical Research Laboratories}

\begin{abstract}
In the age of digital multimedia, demand is bound to rise for television Home Servers that automatically record a viewer's favorite programs so that he/she can watch them at any time. We have developed an experimental Home Server on which a recorded HDTV program can be played back while recording another digital HDTV program. Using a new HSMS (hierarchical storage management system) we proposed, it was able to store HDTV programs for 4 hours and was as small as thickness of flat displays. This paper describes the outline of the experimental system and aims to clarify the recording requirements for hard disks and tapes by examining the read/write performance of hard disks on multi-channels and the nonlinear accessibility to programs recorded on tapes.
\end{abstract}

\section{1. はじめに}

ディジタル放送時代の家庭用記録装置は、 視聴者の好みの番組を自動的に収録し、見た い番組をいつでも简単に取り出せる“いつで も機能“が求められる。このような新しい機 能をもった記録装置をホームサーバと呼んで いる(1)。我々は、ディジタルハイビジョン 放送を収録しながら再生できるホームサーバ 実験装置を開発した。この実験装置は、階層 的記録方式を導入することでハイビジョン番 組を 4 時間収録できる。本報告では、ホーム サーバのシステム構成について述べ、ハード ディスクのマルチチャンネルによる $\operatorname{Read} /$ Write 性能とテープ上に記録された番組の） ンリニアアクセス性能から、ハードディスク
とテープの各記録デバイスに対して要求され る性能を明らかにする。

\section{2 . 実験装置の構成}

I S D Bによるディジタル放送では、ハイ ビジョン番組（MPEG-2 MP@HL）を 約 23Mbps でサービスすることが想定されて いる。ホームサーバによる“いつでも機能” の実現には、放送中の番組を収録しながら見 たい番組を再生できることが不可欠で、記録 デバイスのデー夕転送性能として 50Mbps 以 上が要求される。また、ハイビジョン番組を 4 時間分蓄積するには、40GB以上の記録容 量が要求される。

このため、今回開発したホームサーバ実験 装置は、記録デバイスとして、半導体メモリ 一（RAM）、ハードディスク、テープを利 用した階層的記録システムとした (2)。

本実験装置の外観を図 1 に示す。パソコン をべースに開発したが、記録デバイスへの記 録再生方式は独自の方法で実現している。そ のハードウエア規模はP D Pなどの壁掛けテ レビに十分内藏することが可能である。

本実験装置のブロック構成を図 2 に示す。 ハードディスクとテープ装置は 1 つ UltraWide SCSI バス上で接続され、記録再生制御 される。ホームサーバの入出力信号は、M P E G-2のTSである。

本実験装置のソフトウエア構成を四 3 に示 す。階層的記録システムを実現する上で、八 ードディスクとテープの各記録デバイスドラ イバー、複数の記録デバイスを制御する記録 
エージェントが重要なソフトウエアモジュー ルである。

\section{3. ハードディスクに要求される性能}

階層的記録システムを実現する上で、ハ一 ドディスクが 1 次メモリーとして重要な役割 を果たす。テープや光ディスクなどの 2 次メ モリーに記録された番組の高速なアクセスを

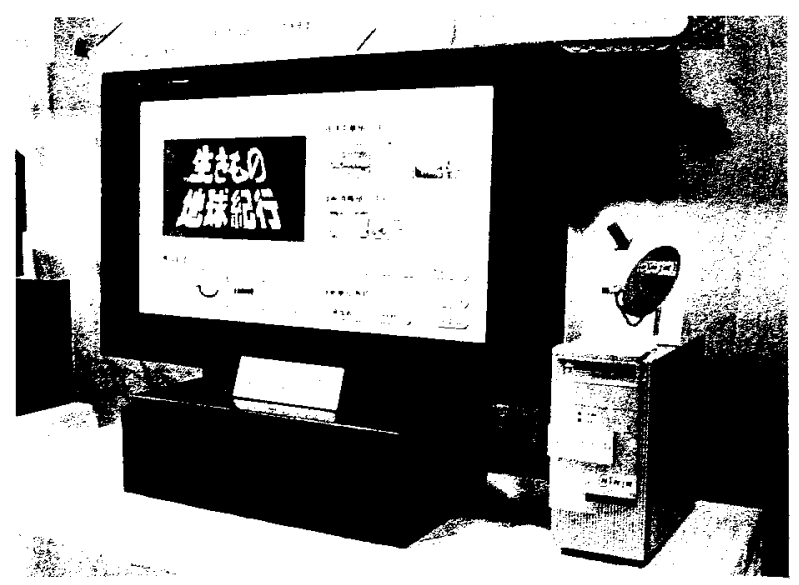

図 1 ホームサーバ実験装置の外観

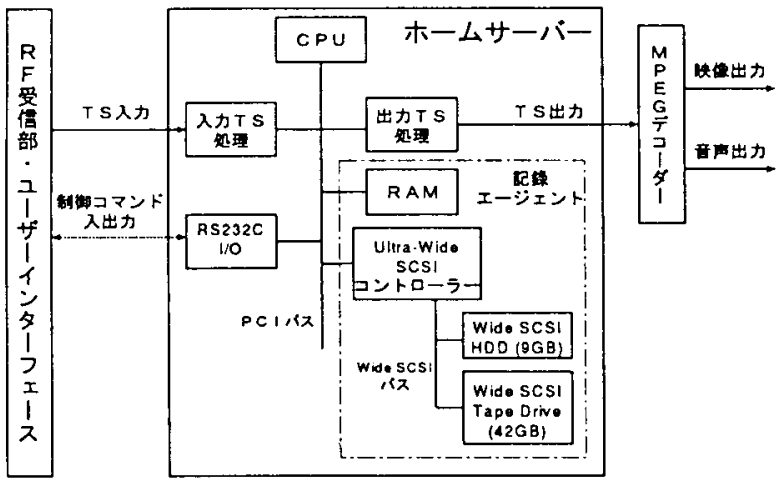

図 2 実験装置のブロック構成

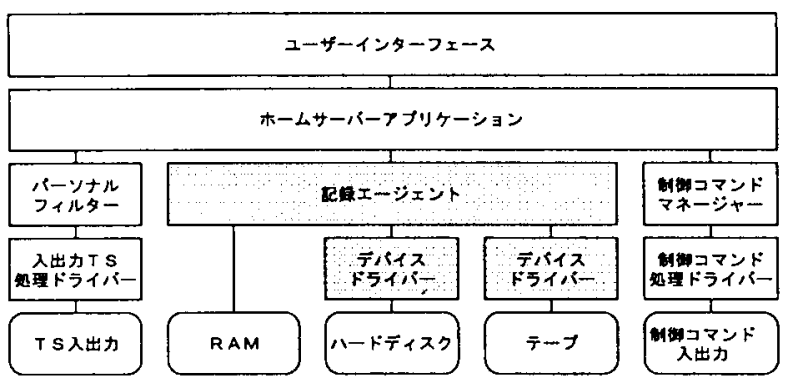

図 3 実験装置のソフトウエア構成
実現するには不可欠な記録デバイスである。 しかし、ハードディスクは、コンピューター 用に最適設計されており、映像アプリケーシ ヨンの 1 次メモリーとして利用するにはいく つかの課題がある(3)。コンピュータ一用途 では瞬時的なデータアクセス性能を重視して いるのに対し、映像や音声のアプリケーショ ンではある一定時間内に必ずあるデー夕量を 処理することができないと記録や再生に破綻 をきたす(4)。

我々は、高速な速続デー夕転送を保証し、 映像の基本データサイズと同等なブロックサ イズでハードディスクヘデータの記録再生が できるビデオハードディスク技術を開発した (5)。この技術の導入により、ハードディス クへ同時記録再生する場合に発生するシーク 回数を大幅に軽減することができ、映像アプ リケーションに対してハードディスクのもつ 性能を最大限に生かすことができる。

ユーザーが使用できる実効的な連続読み出 し性能を今回使用したハードディスクについ て測定した結果を図 4 に示す。最外周のゾー ンで約 117Mbps、最内周のゾーンで約 79

Mbpsである。このドライブのカタログスペ ックによる内部デ一タ転送速度は、122Mbps 〜177Mbpsである。したがって、ユーザーが 使用できる実効的なデー夕転送効率は約 $65 \%$ である。ハードディスクを利用したシステム 設計を行う場合、カタログスペックは実効的 な性能に対してかなりのオーバーヘッドを含 む值であることを認識しておく必要がある。

図 5 は、使用したハードディスクのシーク 特性を測定した結果を示す。最内外周間のフ ルストロークシークは約 $15.5 \mathrm{msec}$ である。記 録しながら再生する場合、必ずシークを伴な いながら記録または再生が実行される訳で、 このシーク性能がホームサーバのシステム設 計に及ぼす影響は大きい。これもカタログス ペックには通常、平均シーク時間が記載され ており、このドライブは約 $8.5 \mathrm{msec}$ が公称值 である。したがって、実効的にはこの倍近い シーク時間が発生する可能性がある訳で、シ ステム設計上十分に考慮しておく必要がある。 
また、尖際にハードディスクへアクセスす るデータブロック烄によってその1回あたり の処理にかかる時閒が大きく変わる。その関 係を測定した結果を図 6 に示す。この測定結 果をもとに、ハードディスク単体の性能とし て、要求される入出力デー夕転送レートに対 して 1 秒間に何回までI /Oを開くことが可 能かを評洒することができる。今回使用した ハードディスクについてその絬果を図7に示 す。この結果からマルチチャンネルによる八 一ドディスクのアクセス性能を評価でき、そ の設計指針を得ることができる。その具体例 について次に説明する。

記録しながら再生する場合、ハードディス

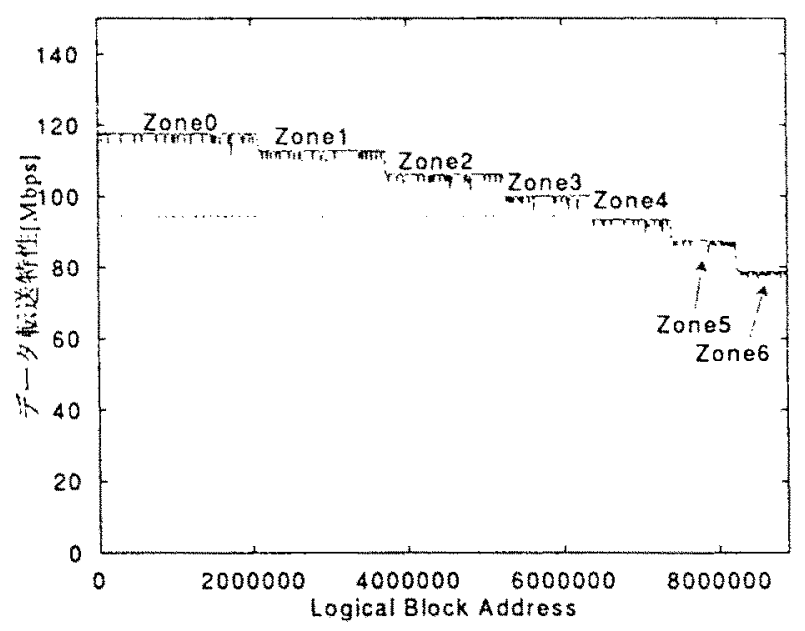

図4寒効的な連綍デー夕読み出し性能

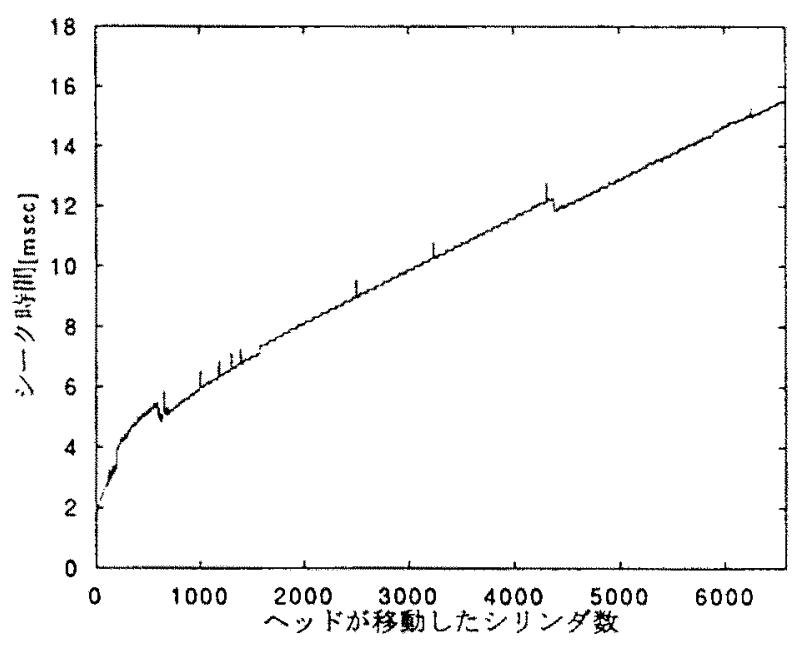

図 5 シーク性能
クへの入出力転送レートとして 2 チャンネル 分の带域が必要となる。今回の場合、46.62 Mbpsの带域が必要となる。ビデオハードデ イスクのようにS C S I インターフェースに よるデー夕転送など、ハードディスク外部側 の処理で性能のボトルネックが生じない場合 を仮定すると、1秒間に笑行するシークが50 回までなら破綻なく処理できることがこの測 定結果からわかる。通常のパソコン瑾境の○ Sファイルシステムを使用して同様なデータ 入出力をさせると、少なくても 1 秒間に 100 回以上のシークがハードディスクに要求され 処理に破綻をきたす。今回開発した実験装置 では、記録データブロックサイズを $1 \mathrm{MB}$ と することで、9回のシークが発生するだけで 斎み、ハードディスクの性能の約 $56 \%$ ぐらい

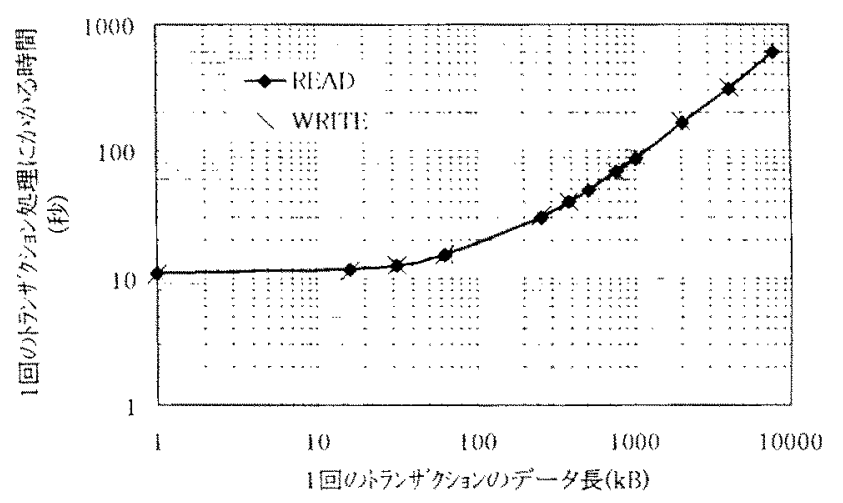

図6 トランザクション処理性能

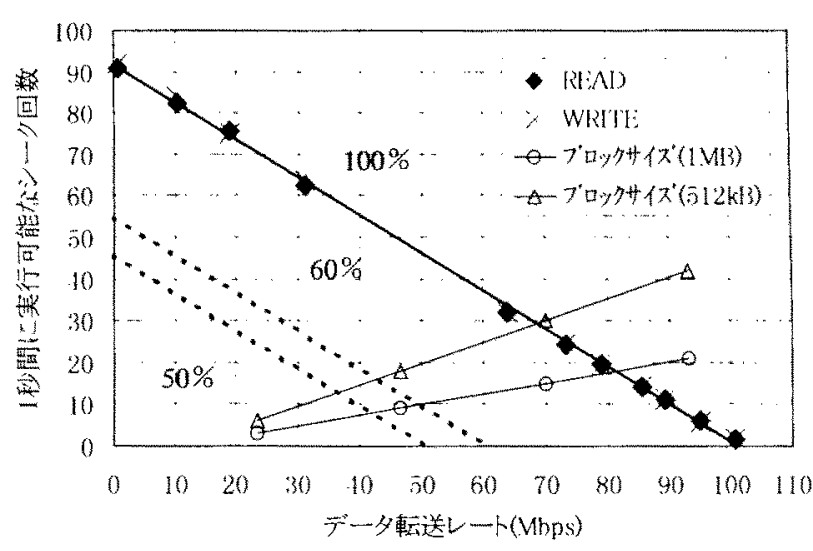

図 7 マルチチャンネルによるハード ディスクのアクセス性能 
しか使用せずに実現できていることがわかる。

このように、ハードディスクの性能を最大 限に生かすことで、ディジタルハイビジョン 放送を 1 台のハードディスクで収録しながら 再生することが实現でき、コンパクトなシス テム構成を可能とした。

映像アプリゲーションは時間管理されたデ 一夕処理が妿求される。したがって、単にデ 一夕を readまたは writeする時閒だけでなく シーク時間が大きな影響をもつ。ハードディ スクの性能として、実効的な連続デ一夕転送 性能の间上とともに、シーク性能が改善され ることを期街する。

\section{4.テープに要求される性能}

本実験装置では、半導体メモリー、ハード ディスク、テープの 3 種類の記録デバイスを 利用しているが、これらを単に組合せただけ でなく、各々の記録デバイスの特性を生かし ながら 1 つの番組の記録および再生を行って いる。コンピュータデータの記録・再生時に 用いられるファイルという概念をなくして処 理することで、従来のコンピュータでは行え ない複数の記録デバイスに対して同時に動的 なアクセスができる。これにより、以下に述 ベるような従来はできなかったテープからの インタラクティブな再生を実現した。

\section{1 テープから待ち時間のない頭出し再生}

現在の家庭用VTRでは、記録された番組 の䫓出しに数分待たされることがある。本実 験装置では高速な頙出し再生を坚現するため に、番組冒頭部分をハードディスクに記録し ている。冒頭部分を再生中にデープ装置は再 生する番組のサ一千動作を行い、番組内容の 記録してある部分に追いついた時点でハード ディスクからテープの再生にシームレスに剩 り換えることを可能にした。これにより、テ 一プに記録した番組の待ち時間のない視聴が 行える。本実験装置では、42GB 容量の力セ ットテープを使用することにより、4時間以 上のハイビジョン番組を収錄でき、それらを 待ち時間なしに見ることができる。

\section{2 テープからのノンリニア再生}

テープ装置は、機峨的なテープ送りにより シークを行うことから高速なランダムアクセ スができない記録デバイスである。しかし、 高速なデ一夕の記録再生が可能であるため、 番組の実時間よりも短い時間でデー夕転送を 行うことができ、その時間差を利朋して次の 再生シーンの頙出しを完了させられれば、図 8 に示すようにシームレスなノンリニア視聴 が拣現できる。本方式では、テープの持つ高 速デー夕転送性能を生かして、そのサ一千性 能を改善することで、これまではできなかっ たテープからのインタラタティブな再生を篹 現している。

本実験装置において、テープからシームレ スに再生可能なノンリニアアクセス性能を測 定した結果を図 9 に示す。この結果から、1 シーンの再生時間を 30 秒に設定すると、約 20 分先までジャンプしてもシームレスなノン リニア再生ができることがわかる。

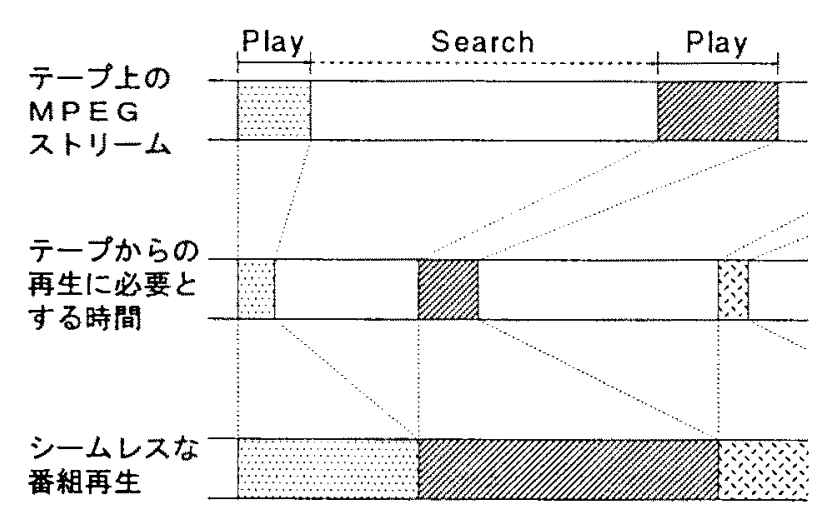

図 8 テープからのノンリニア再生

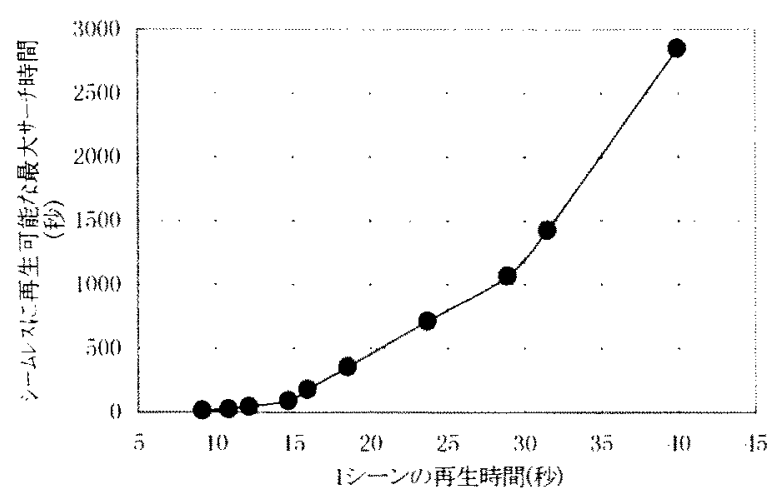

図 9 テープからのノンリニアアクセス性能 
ホームサーバのような映像アプリケーショ ンに対して、テープに期街される性能はでき るだけ契時間よりも离速に記錄再生できるこ とである。これにより、その遅いアクセス性 能を力バーでき、ディスクメディアと间様な サービスを提供できる叮能性がある。

\section{5.まとめ}

皇速大容是かつコンパクトなホームサーバ のアーキテクチャーとして階層的記録う式を 提案し、その実験装置を開発した。

ホームサーバのシステム設計において、ハ ードディスクのマルチチャンネルアクセス性 能と、テープからのノンリニアアクセス性能 を評価することが、その設計指針を得る上で 重要であることを述べ、その評価結果から八 ードディスクとテープに要求される性能につ いて考察した。

今回、映像アプリケーションに対するハー ドディスクの性能を的確に評価した上で、ビ デオハードディスク技術を適用することで、

ディジタルハイビジョン放送を 1 台のハード ディスクで収録しながら再生できる方式を実 現した。さらに、テープとの組合せにより、 4 時間以上のハイビジョン番組を収録でき、 それらを待ち時間なしに見ることができる方 式を寒垷した。

\section{参考文献}

(1) 案岡: “デジタル放送とホームサーバー”, 映情学会作次大会, S1-4,pp.438-441, July, 1998

(2) T.Kurioka, H.Minami, H.Okuda, J.Numazawa, A.Yanagimachi and H.Ohshima: "Television Home Server for Integrated Services - Toward the

Realization of ISDB “Anytime” Services -“, IEEE ISCE'97, pp.250-253, December 2-4, 1997

（3）栗岡，南，藤澤: “高画質映像情報のデ 劝記録への期待 〜ビデ机ード ‘゙ 仍〜”, 映情学会年次大会, S2-6, pp.422-425, July 1997

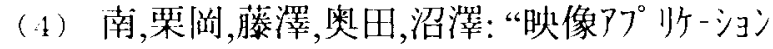
に刘するハードデ仅装置の新しい評価手 法の一検討”, 映情学技報, Vol.21, No.58, 1997

(5) T.Kurioka, H.Minami, H.Okuda, H.Ohshima : "A New Video Hard Disk System for Multimedia Program Production", IEEE Transactions on Broadcasting, Vol.42, No.3, pp.222-228, 1996 